\title{
Indirect Motivation of Derivatives in Modern Russian
}

\author{
Galina Aleksandrovna Voevodina* \\ Yelets State Bunin University, Yelets - 399770, Russian Federation; monblan@yandex.ru
}

\begin{abstract}
The article discusses the indirect motivation associated with the process of word formation, reflecting the functional importance of derivatives marked by the expressive connotation. The description of word formation specificity with regard to figurative motivation of nouns relating to the thematic group 'man' is a topical subject of derivation research connected with the study of the dynamics of the derivation figurative resource and folk life culture development. The purpose of this paper is to identify the dynamic processes realized in the action of word formation mechanism included in the forecasting of trends in the development of the potential word formation and its peculiarities for certain models and bearing native cultural identity in language consciousness and linguistic traditions, sometimes manifested through the inner form of the word, used in figurative motivation description. The article analyzes the unique nature of connotations of figurative words, which reveals the types of figurative word-formation motivation and forms the modern idea of the problem of indirect (figurative) motivation of derivatives (derivative words). Defining the functional specificity of derivatives with figurative motivation, it is important to establish and explain the semantic derivation and the problem of indirect motivation of derivatives. Unlike direct naming units indirect secondary nominations under analysis represented by derivational motivated words (of different types of motivation) have been registered in the words of spoken language, including those with connotations. The peculiarity of representation of the internal derivation form in defining dictionaries records functional difference and pragmatic features in the meanings of derivative words with figurative motivation.
\end{abstract}

Keywords: Derivative, Figurative Motivation, Internal Form of the Word, Metaphorical, Word-Formation Formant

\section{Introduction}

The studies by V.V. Vinogradov ${ }^{4}$, G.O. Vinokur ${ }^{5}$, V.V. Lopatin ${ }^{6}$, O.P. Yermakova, E.A. Zemskaya ${ }^{9}$, I.A. Shirshov ${ }^{18}$ are works which allow explaining the basic concepts of synchronous motivation of a word and problems of figurative motivation. The issue of the typology of changes in the meanings of words and their regularity is important as well. To study the universal semantic laws ${ }^{1-3}$ the identification of specific types of semantic changes of words becomes urgent. According to V.V. Vinogradov ${ }^{4}$, the term 'motivation' is most often associated with the concept of the inner form of the word, which reflects "the figurative way of expressing a particular meaning due to psychological, cultural and historical features of the environment and the epoch". "The perception of the motivational relations does not always correspond to the etymology of the word derived, because this 'derivational' perception may change in the history of language". G.O. Vinokur $^{5}$ considered that distinguishing distinctive features of the semantic structure of derivative word an important fact is the relations of words: "The meaning of words with the derivative basis is always definable by reference to the meaning of the corresponding primary stem". The problem of figurative motivation was reviewed by V.V. Lopatin ${ }^{6}$, highlighting special, metaphorical motivation, the essence of which is that "the figurative meaning occurs in certain words only at the level of a motivated word, in its word-forming structure".

\section{Literature Review}

The nature of semantic connection of the base form and the derived one which differs by its metaphorical property is the main cause of inactive derivational potential of word-forming metaphor. Derivational metaphors of

* Author for correspondence 
characterizing type perform the nominative function: They characterize aspects of human personality: Bosyak [tramp - 'squalid, impoverished person from a declassed walk of life']; litsemer [hypocrite - 'a two-faced person']. Such lexical units combine in their semantics nominative and connotative components. Sometimes monosemantic substantives internalize figurative and associative meanings of the base words: Bezumets [madman denoting 'extremely reckless' with the label 'colloquial']; podruchnik [sidekick] - pejorative 'posobnik' ['candle-holder']. Figurative metaphorical motivation is related to the connotative modification meaning, i.e. the property of the subjective assessment and the expressive function: Murlo [mug] - derogatory 'about a man provoking hostility'. In the studies of Russian scientists connotative suffixes of the modification type are noted. L.A. Bulakhovskiy studied the word muzhlan [bumpkin] among the words formed by adding the suffix -an (-yan): "The suffix -an (-yan), detached or adapted (selected according to the similarity of the borrowed word) is associated with the meaning of rudeness: Buyan [brawler], gorlan [bawler], muzhlan [bumpkin (a rough man; cf.: oblastnoye muzhlo - 'neotyesa' [lout]; words lentyay [lazybones], slyuntyay [wimp] "denote a man who is despised, disgusted". The word duralyey [fool] is singled out among "the entities standing alone with the evident emotional coloring: vral [liar], duralyey [fool], torgash [huckster], kudryash [curlyhead]"7. V.V. Vinogradov said that "the word muzhlan [bumpkin] is scornful, pejorative designation of a rude, ill-mannered person, peculiar to the familiar style of speech" Vinogradov ${ }^{4}$. The noun durynda [nitwit] is included by the scientists into the terms of contemptuous expressive nominations. The colloquial derivational words gulyona [lounger] and tikhonya [goody-goody] differ by the connotative meaning: suffixes - yon / - on, which are familiar and ironic, affectionate and humorous, were recorded in the category of common gender ${ }^{1}$. Differentiation of figurative and expressive language units as the representatives of mentality and character of the Russian people is reflected in the recent studies ${ }^{8}$.

E.A. Zemskaya ${ }^{9}$ identified the type of motivational relations "when the derivational word resulting from the base form has a figurative meaning itself: Molokosos [whipper] 'people unable to sensibly judge of anything because of their youth and inexperience'; lizoblyud [sycophant] 'an obsequious man who loves to live at the expense of others'; golovorez [thug] bandit 'bandit". A.N. Tikhonov ${ }^{10}$ stated the metaphorical uniqueness of deducing meaning of words of this kind from the meaning of their constituents. This type of motivational characteristic is understood by domestic and foreign scientists as 'folk etymology'11-13. System properties of derivatives with metaphorical motivation detected in synchronous aspect are presented in the lexical-semantic organization of word-building metaphors that differ by typology, reflecting the degree of their semantic connection with base words. In their direct nominative semantics such derivation metaphors do not have the semantic components included into their constituent morphemes: Podkabluchnik [henpecked] - colloquial "the one who is subordinate to his wife, henpecked. As a result of the formation of the metaphorical meaning of the derivative transformation occurs, i.e., semantic shifts, difference of meanings of the derivational word and the base word in the expressive metaphor.

\section{Methodology}

While researching word-formative structure with indirect synchronous word-formative motivation a partial synchronous and diachronic approach including methods of comparative analysis and the analysis of word-formation semantics was used. In carrying out the research work a synchronous approach was applied. The logical semantic method based on the principle of using the dictionary interpretations in establishing semantic relationships of words was used. Many derivation metaphors historically go back to the lexical metaphors, i.e. their figurative meaning is the result of semantic derivation: Molokosos [whipper] 'feeding mother's milk'. The source language material is presented by motivated figurative names of a man, extracted by continuous sampling method from the contemporary dictionaries of the Russian language. In the study of the connotative vocabulary word-formation and semantic analysis of the vocabulary was conducted in terms of consideration of the secondary nomination problems. When extracting examples the comparative analysis was used according to which words with direct and indirect nomination and words with the inner form with account of types of word-formation motivation were examined. Then, derived words more commonly used in the modern language (stylistically unmarked or marked) were specified. Also the uniqueness of motivation of expressive words was taken into account. Reflecting the history of the developing of certain types of word-formation, 
expressive and evaluative language system includes derivation metaphors: connotative words pustomelya [windbag], goloshtannik [beggar], pustobryokh [bag of wind], negodyay [scoundrel], nedotroga [touch-me-not], merzavets [rascal] and evaluative and expressive with figurative meaning: pustomyelya [chatterbox], merzavets [rascal]; their dynamic nature manifested itself "in the movement towards stylistically substandard language resources and the gradual reservation of the characterizing function for the word-formative metaphors"14. The results of approaches to defining and analyzing expressive word-formative metaphors by linguists are reflected in the findings, showing the synonyms and the system of negative assessments of various types of word- formative metaphors that determine their functional properties.

\section{Results}

The main difficulties in the use of 'the rule' of derivational semantics have been associated so far with the updating of the concept of systemization and generalization of motivation manifestation in derivates on the basis of some common mechanism of formation of figurative meanings of morphologically motivated words. The scientific novelty of the study is to present a review of types of figurative motivation of derivationally motivated words, because "in any language that is derivationally marked what is biologically, socially or culturally significant in the minds of the people"15. The phenomenon of this kind that has been described in the linguistic works, is observed, in particular, in the field of figurative characteristics of derivatively motivated words that are word-formation models in reflecting the Russian linguistic worldview through the transferred characteristics of the different aspects of human life, which allows us to speak of the model creation of the image of man in the Russian linguistic worldview. The methods and permissible limits of semantic variation margins are universal or specific to each language ${ }^{16}$.

Our focus is in the area of derivational semantics of derivative words (derivatives), assimilating figurative meaning, reflected in the presentation of the vocabulary description of the 'man' naming. The connotative metaphor with the figurative meaning in its initial nominative meaning of the conceptual sphere 'animal' is used as an expression of disapproval: Gadina [viper], colloquial substandard, abusive, zaraza [disease] abusive, about somebody, something causing displeasure, irritation, anger'. The semantic and stylistic nuances of the usage of words in speech serve to express the assessment: a rebel - A rebel in the sense of 'instigator', labeled as 'obsolete'. The presence of associative-figurative component as a motivational characteristic acts as a base of "evaluation feature and stylistic labeling, tying the denotative and connotative content of a language unit" ${ }^{17}$. The semantics of associative type is formed in nouns with a motivational characteristic, reflected in the indirect meaning of the motivator: Naparnik [partner], colloquial 'pogodok' [halver]. The ethical and aesthetic senses in the structure of the connotative meanings are connected. The relation to a person in the speech activity may be negative, disapproving, insulting, derogatory and even abusive: Podkhalim [sycophant] - 'the person who is obsequious with, curry favor with somebody, trying to win, to achieve something. Some words acquire the ability to express ironically disapproving meaning in the colloquial speech: oborvysh [ragamuffin] - colloquial 'about the child'. Stylistic synonyms of the word oborvysh [ragamuffin] - colloquial, 'a man in worn-out clothes' the words bosyak [tramp], brodyaga [hobo] are expressive means: alongside with the word golodranets [deadbeat] - pejorative 'ragamuffin' express a rough estimate of the addressee. The word golodranka [deadbeat (of a woman)] is given in the sense of 'ragamuffin, poor (about a woman)' labeled as 'colloquial', with a connotation of scorn. Substandard meanings of the expressive wordformative metaphors depend on the semantic differences between the motivator and metaphorical derivative. The partial loss of the meaning at maintaining semantic relationships is characteristic of words gorlopan [roarer], colloquial, 'the same as gorlan [bawler], colloquial, 'about a person who roars, screamer'.

The idea of the dynamics of figurative resources of Russian culture requires fixation of the connotative meanings involved into the type of associative motivation. The expressiveness of these words is preserved in the connotative meaning of such words as goloshtannik [ragamuffin] - pejorative 'deadbeat'; guboshlyop [chawbacon] - figurative, pejorative, 'scatterbrain, muddler'. Associative motivation is characterized by semantic links of deducibility of derivative in the presence of motivational characteristic, the inner form of the base word $^{18}$. Specificity of the association feature, according to D.N. Shmelev" ${ }^{19}$ is that it "is not usually observed in the interpretation of the word in its basic meaning", but "as if only potentially accompanies it". In the word-formative 
derivation there is the actualization of the inner form that the basis for the name becomes the image, causing associations. Lexical and grammatical (word formation) means of expressing the connotative semantics included in the semantic system of a language connotative words, suffixes and word-formation models, are widely used in the Russian colloquial speech.

Connotative naming of a person of moral and ethical content, which are characterized by expressive coloring, semantic diversity, reflect self esteem of a Russian, his worldview. As part of these words there is a redistribution of meanings according to their relevance among native speakers. Word-formation models with semantics 'appearance' are a common means of expressive characteristic of a man, emotional assessment of his individual qualities: Bogatyr [strapping fellow] colloquial, 'about a man of tall and strong build, a lot of physical strength, perseverance'; 'traits of character that reflect a person's attitude to other people': Volshebnik [magician] - 'the person fascinating somebody with his intelligence, knowledge, skills, etc.; gorlopan [roarer] 'one who expresses his dissatisfaction, disagreement with cry, who says a lot in a loud voice and in vain, not listening to the interlocutor'; yornik [buffoon] - old., 'the one who taunts at someone, something'; starukha [an old woman] - familiar and ironical 'wife or a close female friend, girl'; zadirala [teaser] - colloquial 'instigator of quarrels and fights, bully'; zanuda [boring] - colloquial, substandard 'very tedious and annoying people'; zlodey [villain] colloquial, 'about a person who causes irritation, anger and so on by his actions'; naushnik [informer] - pejorative 'third ear'; fokusnik [magician] - colloquial, 'a clever man, capable of unseemly antics; dodger'; shtuchka [a pretty thing] - colloquial, 'about a woman capable of the antics, tricks or clever inventions'; evaluations of the social and professional status of the individual in society, collective: khalyavshchik [freeloader] - jargon 'slacker; freeloader'.

The connotation and expressiveness arise as a result of using language units in the communication process. The function of a word as a means of expressing the evaluation transmits the form of verbal behavior. The meaning of assessment of the words in a figurative use is realized in the speech situation: Words when they are used to characterize a person in a figurative sense always possess expressiveness. Among the derived words of colloquial speech the most frequently used are those that reflect the everyday interpretation of the formation of a transferred motivation. Derivatives assimilating figurative meaning frequently present the cases of figurative motivation ${ }^{18}$. Figurative characteristics in naming a person receive a typology of evaluation. Derivational models with semantics 'common traits of character' are used in the indirect naming: balamut [troublemaker] - informal, 'the one who raises concern, disorders, strife'; balagur [jester] informal, 'the one who jests; a messer'; bedokur [mischief] - informal, 'pickle, prankish'; balabol [motormouth] substandard, 'chatterbox, babbler'; vetrenik [a changeable sort of person] - informal, 'harum scarum'; fokusnik [magician] - informal, 'a capricious, fastidious man'; bezdar [third-rater] - derogatory, informal, 'about someone without talent'; starik [gaffer] - informal, 'an experienced, wordly-wise person who already knows some business, works (as opposed to the beginner)'; 'certain temperament': zhivchik [swifty] - informal, 'about a frisky, trotty, very mobile person', neposeda [fidget] informal, 'a restless person (about a child)'; 'business and professional personal qualities': stukach [a snitch] informal, derogatory 'informer, enlightener'. It is obvious that the figural value gives an expressive connotation to derivatives in this type of motivation.

\section{Discussion}

It is known that the concept of 'motivation' is wider than concepts of 'word-formation motivation' and 'derivation'. The problem of the typology of word-formation motivation gained its development of the theory of degrees of word-formation motivation, developed in the late $20^{\text {th }}$ century, which allowed addressing the problem of motivation of expressive words from a new angle The researchers note the existence of a group of such words for which the terms 'formal-expressive ${ }^{20}$ or 'expressive motivation ${ }^{21}$ are used when describing motivation and it is called a relative motivation ${ }^{22}$.

Apparently, the issue about motivation and dividedness of words considered has to be solved depending on the nature of the semantic relation of motivated derived word with motivating base word taking into account the degree of motivation. In the case of the special nature of the semantic or formal motivation it is necessary to distinguish models established sometimes at the relation of derived word with the base phraseologism: slyuntyay [wimp] - 'the one who drools' - impolite, substandard 'cry'; 'cranky, crying, complaining at smth'; 'to be passive, absent-minded, inattentive'; nakhlebnik [freeloader] 'the one who lives on the bread out of smb'. 
In the colloquial vocabulary of modern Russian language there are words like zuboskal [scoffer] (E.A. Zemskaya) and the words-idioms verkhoglyad [skygazer], lobotryas [idler], vetrogon [whiffler] ${ }^{23}$, which are also characterized by conventional semantic relations. The question of the origin of the word buzotyor [hue-andcrier] - colloquial, 'kicker' was discussed by researchers. In the dictionary From the History of Russian words there is a brief commentary about the origin and function of the word buzotyor [hue-and-crier]. The word buzotyor [hueand-crier] - 'bully, brawler', known in this same sense in Ukrainian and Belarussian (cf. Ukrainian buzoter, Belarusian buzatsyor) is one of the many expressive entities that were included in the standard language in the era of the Revolution of $1917^{24}$. S.A. Koporkiy mentions the word buzotyor [hue-and-crier] in the list of the youth language units of the 20-ies, as penetrated from thieves' jargon. Perhaps buza(o)tyor [hue-and-crier] - 'a farmerkicker' was motivated by phraseological combination buzu zateret [kick up a row] - 'make a scandal'.

According to another point of view, a compound word buzotyor [hue-and-crier] originated in the dialects and was brought into the literary language therefrom. It is formed by contraction (as buffer from rub floors or scoffer from grin) from idiomatic combination buzu teret [kick up a row] in the meaning 'to arrange a mess' literally 'stir home brew', recorded in the Yaroslavl dialect in the meaning 'to touch, tease $\mathrm{smb}^{26}$, $\mathrm{cf}$. similar to make a mess $^{24}$. It is expected that a derivative word buzotyor [hueand-crier] has its derivation synonym - the word buzila [hell-raiser], in case if to consider them formed from the verb buzit [kick up a row]. In the model of formation of words related to the regulatory and general vocabulary, the derivative pravdolyub [truth-seeker] has a derivation synonym pravdolyubets [lover of truth]. Derivational models of such words as tolstosum [moneybags], sredneves [middleweight], tyazheloves [heavyweight] - an athlete of medium or heavy weight' functionally identical to complex suffixal type (cf. ostroumets [mid wit]). This type of words is characterized by derivational synonyms: skvernoslov [foul-mouthed], ostroslov [wit] and skvernoslovets [hardmouthed man], octroslovets [wise cracker].

The functional aspect of motivology evolves in identifying the role of the inner form of the word in terms of a language worldview. "Actualization of motivation of relations" promotes "a thematic dependence of speech utterances" 27 . In such figurative motivation model derivatives from verbal stems which are marked by stylistically limited use where the functional and stylistic component "is introduced into the semantics of the word by a social function of a language" present the scientific interest ${ }^{28}$. In a language as "a component of culture" 29 in word-formative motivated words as a stylistic means "the connection of such words with motivating ones is based not on the logic of relations between phenomena", ${ }^{21}$ but on the connotations of colloquiality whose existence is due to the socio-linguistic factors.

\section{Conclusion}

Thus, the models of the analyzed derivatives (types of indirect motivation) in the naming of 'man' are described as an expressive language means. The formant -1- is used as a means of expressing a transferred motivation in one model of the colloquial style. Sometimes the indication of the physical action is included into the content of derivatives: gromila [housebreaker] - colloquial 'burglar'; vyshibala [bouncer] - colloquial, derogatory 'employee (in restaurants, cafes) who expels troublemakers'. The emergence of figurative motivation is manifested in the derivational metaphor and in the word-formative mechanism itself. The associative motivation of derivatives of the naming 'a man' represents word-formation models in imaginative reflection of a certain linguistic worldview: Figurative characterization of various aspects of human activity. Distinguishing peculiarities and types of functional and expressive vocabulary (cf. gadina [viper], colloquial, substandard, swear-word), as well as the type of connotative components: 1. Emotive and evaluative (cf. chinusha [bureaucrat], derogatory); 2. Functional and stylistic (cf. vyshibala [bouncer], colloquial, derogatory) identifies the factors the consideration of which the words analyzed can be differentiated in some way. Thus, lexical and word-formation means of qualitative and connotative semantics of naming a man are analyzed, some questions on the specifics of the expression of the evaluative component of connotation are considered. In the material considered while studying the actualization of types of motivational relations, different degrees of relations with motivational peculiarities are established which implement types of associative, transferred and related motivation depending on the nature of the semantic relation of these words, retaining motivation in different ways.

The methods of vocabulary interpretations do not always include the typical features of motivational 
attribute such as associative motivation into the evaluative vocabulary characteristic: shtuchka [a pretty thing] 'a perfidious woman, brodyaga [tramp]. The evaluativity is realized through the internal form of the word in the stylistic means, i.e., updating the image, associated with derivational properties. When using not only lexicographical sources in the presentation of verbal behavior in society, but also 'extralinguistic circumstances' $^{30}$, the context of the modern use of words with indirect motivation an indicator of change, preservation and development of national specificity of Russian language culture can be considered. Possible prospects for further research on the topic are associated with the adjustment and the formation of ideas about the classification of imaginative and expressive lexis, taking into account the pragmatic, ethical and aesthetic parameters $^{31}$ that has not yet been done. And taking into consideration of this direction of research development in the future it is necessary to consider the possibility of using the findings in compiling of high-quality directories for the purpose of their alignment and improvement.

\section{References}

1. Gak VG. K probleme obshchikh semanticheskikh zakonov [On the problem of the common semantic laws]. General and Romance linguistics. Moscow. 1972; 144-57. [in Russian].

2. Arutyunova ND. Yazykovaya metafora (sintaksis i leksika) [Language Metaphor (Syntax and Vocabulary)]. Linguistics and Poetics. Moscow; 1979. [in Russian].

3. Teliya VN. Metaforizatsiya i eyo rol v sozdanii yazykovoy kartiny mira [Metaphorization and its Role in the Creation of a Language Worldview]. The role of human factor in language. Language and world picture. Moscow. 1998; 173-204. [in Russian].

4. Vinogradov VV. Russkiy yazyk [Russian Language]. Grammatical doctrine of the word. Moscow. 4th ed; 2001. [in Russian].

5. Vinokur GO. Zametki po russkomu slovoobrazovaniyu Tekst [Notes on the Russian Word Formation Text]. Selected works in the Russian language. Moscow: Uchpedgiz. 1959; 419-42. [in Russian].

6. Lopatin, VV. Metaforicheskaya motivatsiya v russkom slovoobrazovanii [Metaphorical Motivation in Russian Word Formation]. Actual problems of Russian word formation. Tashkent. 1975; 143(1):53-7. [in Russian].

7. Bulakhovskiy LA. Course of Russian Literary language; 1953. [in Russian].

8. Lukyanova NA. Obraznye i ekspressivnye nominatsii kak reprezentanty kartiny mira i mentalnosti nositeley russkikh sibirskikh govorov v period ikh pervonachalnogo formirovaniya (po materialam "Slovarya russkoy narodno-dialektnoy rechi v Sibiri 17 - pervoy poloviny 18 v." L.G. Panina) [Imaginative and Expressive Nominations as Representators of Worldview and Mentality of Russian speakers of Siberian Dialects in the Period of Initial Formation (Based on the "Dictionary of Russian Folk Dialect Speech in Siberia 17-the first half of the 18 century", Panin, L.G.)]. Herald NSU. Part: history, philology. Philology. 2011; 9(10):11-20. [in Russian].

9. Zemskaya EA. Vidy semanticheskikh otnosheniy slovoobrazovatelnoy motivatsii [Types of Semantic Relations of Word-Formative Motivation]. Wiener Slawistischen Almanach. Band. 1984; 341. [in Russian].

10. Tikhonov AN. Slovoobrazovatelnaya motivirovannost odnokorennykh slov [Word-formation of Motivation Cognate Words]. Russian syntagmatics and paradigms. Krasnodar. 1991; 110-21. [in Russian].

11. Herberg D. Wortbidung und Expressivität. Sprachpflege. 1979; 10:206-8.

12. Fleischer W, Michel G. Stilistik der deutschen Gegenwartssprache. Leipzig. 1979; 341.

13. Schippan Th. Lexikologie der deutschen Gegenwartssprache. Leipzig. 1984; 307.

14. Ogoltseva EV. Obraznyy potentsial russkogo otsubstantivnogo slovoobrazovaniya (funktsionalno-pragmaticheskiy aspekt) [Figured Potential From-substantive Russian Word Formation (Functional and Pragmatic Aspect)]. Monograph. - Moscow. 2007; 326. [in Russian].

15. Vendina TI. Slovoobrazovanie kak istochnik rekonstruktsii yazykovogo soznaniya [Word Formation as a Source of the Reconstruction of Linguistic Consciousness]. Questions of linguistics. 2002; 4:42-72. [in Russian].

16. Paducheva EV. Dinamicheskie modeli v semantike leksiki [Dynamic Models in Semantics Vocabulary]. Questions of linguistics. 2006; 4:101-9. [in Russian].

17. Yartsev VN. (Ch. Ed.) Lingvisticheskiy entsiklopedicheskiy slovar [LES] [Linguistic encyclopedic dictionary]. Moscow: Soviet Encyclopedia. 1990; 685. [in Russian].

18. Shirshov IA. Tipy slovoobrazovatelnoy motivirovannosti [The Types of Word-Formation]. Philology. 1995; 1:41-54. [in Russian].

19. Shmelev DN. Sovremennyy russkiy yazyk. Leksika [Modern Russian. Vocabulary]. Moscow. 1977; 227. [in Russian].

20. Koryakovtseva EI. Sinkhroniya i diakhroniya v slovoobrazovanii: Problemy sinkhronnoy motivirovannosti slov [Synchronic and Diachronic Word Formation: Problems of Synchronous Motivation of Words]. Basis of breeding sensibly-word-formation dictionary of modern Russian language. Grozny. 1991; 149-50. [in Russian].

21. Ulukhanov IS. Motivatsiya i proizvodnost (o vozmozhnosti sinkhronno-diakhronicheskogo opisaniya yazyka) [Motivation and Derivatives (the Possibility of Synchronous Diachronic Description Language)]. Questions of linguistics. 1992; 2:5-20. [in Russian]. 
22. Rammelmeyer M. Emotion und Wortbildung. Untersuchungen zur Motivationsstruktur der expressiven Wortbildung in der russischen Umgangs - sprache. Gattungen in den slavischen Literaturen. Beitrage zu inren Fomenin der Geschichte. Koln-Wien; 1988.

23. Solodub YP. Slova-frazeologizmy (na materiale sushchestvitelnykh so znacheniem kachestvennoy otsenki litsa i obrazno-semanticheskoy motivatsiey etogo znacheniya) [Words Idioms (Based on the Value of Nouns Qualitative Assessment of the Face and Figured and Semantic Motivation of the Meaning)]. Idiom and word. Collection of scientific works. - Novgorod; 1996. [in Russian].

24. Slovar - posobie [Glossary - allowance] From the history of Russian words. Moscow [joint venture]; 1993. [in Russian].

25. Koporskiy SA. Molodyozhnyy yazyk [The Language of the Youth]. Russian language speech. 1990; 1.

26. Slovar russkikh narodnykh govorov [Dictionary of Russian Folk Dialects]. Leningrad [SRNG]; 1965-1987. [in Russian].

27. Blinov OI. Yavlenie motivatsii slov: Leksikologicheskiy aspekt [The Phenomenon of Motivation Words: Lexical Aspect]. Moscow. 2nd ed. Rev. and add; 2010. [in Russian].

28. Kharchenko VK. Razgranichenie otsenochnosti, obraznosti, ekspressii i emotsionalnosti v semantike slov [Differen- tiation Estimated, Imagery, Expression and Emotion in the Semantics of Words]. Russian language at school. 1976; 3. [in Russian].

29. Vereshchagin EM, Kostomarov, VG. Yazyk i kultura [Language and culture]. Moscow; 2005. [in Russian].

30. Walter H. Kulturologicheskiy fon $\mathrm{v}$ poslovitsakh-'perevyortyshakh'[Culturological Background in Proverbs-Palindromes]. Problems of History, Philology, Culture. Journal of historical, philological and cultural studies. Scientific peer-reviewed journal. Shulezhkova SG (Ed). Dr. of Philology. Number 3 (45). (July-August-September). Moscow-Magnitogorsk-Novosibirsk. Magnitogorsk State Technical University n.b. Nosov GI. 2014;42-7. [in Russian].

31. Chernyshov TV. Filologicheskie aspekty russkoy pravovoy kultury [Philological Aspects of the Russian legal culture]. Problems of History, Philology, Culture. Journal of historical, philological and cultural studies. Scientific peer-reviewed journal. Shulezhkova SG (Ed). Dr. of Philology. Number 3 (45). (July-August-September). Moscow-Magnitogorsk-Novosibirsk. Nosov Magnitogorsk State Technical University n.b. Nosov GI. 2014; 389-91. [in Russian]. 